\title{
PENERAPAN METODE TAKE AND GIVE UNTUK MENINGKATKAN HASIL BELAJAR IPA SISWA KELAS IVA
}

\author{
I. A. G. Sri Udayanti 1,*, P. Nanci Riastini 2 \\ 1 Jurusan Pendidikan Guru Sekolah Dasar. Universitas Pendidikan Ganesha, Indonesia \\ 2 Jurusan Pendidikan Guru Sekolah Dasar. Universitas Pendidikan Ganesha, Indonesia
}

\begin{abstract}
Abstrak
Penelitian ini bertujuan untuk meningkatkan hasil belajar IPA siswa kelas IV A SD Negeri 2 Sempidi setelah penerapan metode Take and Give. Jenis penelitian ini adalah penelitian tindakan kelas yang terdiri dari dua siklus. Subjek penelitian adalah 20 orang siswa kelas IV A. Hasil belajar dikumpulkan dengan metode tes. Data yang dikumpulkan dianalisis dengan deskriptif kuantitatif. Hasil penelitian terjadi peningkatan hasil belajar IPA melalui penerapan metode Take and Give pada siswa kelas IV A. Dapat dilihat dari persentase rata-rata hasil belajar yang diperoleh sebelum tindakan adalah $62,8 \%$. Setelah dilakukan tindakan pada siklus I, persentase rata-rata hasil belajar yang diperoleh sebesar 70,9\% pada kriteria "Sedang". Setelah dilaksanakan perbaikan pada tindakan pada siklus II, rata-rata hasil belajar semakin meningkat mencapai 81,4\% pada kriteria tinggi. Dapat disimpulkan bahwa penerapan metode Take and Give dapat meningkatkan hasil belajar IPA siswa kelas IV A Semester ganjil SD Nomor 2 Sempidi Kecamatan Mengwi Tahun Pelajaran $2016 / 2017$.
\end{abstract}

Keywords:

Take and Give, Hasil

Belajar IPA

\section{Pendahuluan}

Pembelajaran pada hakekatnya adalah proses interaksi antara peserta didik dengan pendidik dan sumber belajar pada suatu lingkungan belajar, sehingga terjadi perubahan perilaku ke arah yang lebih baik (UU No. 20 Tahun 2003 tentang sisdiknas). Dalam proses pembelajaran, terdapat sejumlah pendekatan pembelajaran yang dapat digunakan dan dipilih oleh guru, sehingga dapat dimungkinkan tercapainya tujuan pembelajaran yang diinginkan. Oleh karena itu, guru sebagai pendidik harus dapat menerapkan berbagai alternatif pendekatan atau metode dalam proses pembelajaran dan memilih media pembelajaran yang sesuai, sehingga akan tercipta suasana yang kondusif untuk keberhasilan proses pendidikan di sekolah.

Hal tersebut di atas juga berlaku pada pembelajaran IPA. IPA merupakan salah satu disiplin ilmu yang berhubungan dengan cara mencari tahu tentang alam. Pada hakekatnya IPA adalah sebagai produk, proses, dan sikap. IPA juga sebagai prosedur dan IPA sebagai teknologi. IPA sebagai produk berisi sekumpulan konsep-konsep, prisip-prinsip, maupun hukum-hukum sebagai hasil penelitian dan pikiran para ilmuan. Selanjutnya IPA sebagai proses berisi sekumpulan keterampilan-keterampilan dasar yang mencerminkan suatu proses IPA. (Sutrisno, 2007).

Menurut Nash dalam Hendro Darmodjo dan Jenny R. E. Kaligis (1992) IPA adalah suatu cara atau metode untuk mengamati alam. Cara atau metode tersebut harus bersifat analitis, lengkap, cermat, serta menghubungkan antara fenomena dengan fenomena yang lain. Vessel dalam Patta Bundu (2006) mengartikan IPA sebagai suatu hal atau apa yang dikerjakan para ahli sains (Scientis). Vessel dalam Patta Bundu (2006) mengemukakan "science is an intellectual search involveng inquiry, rational through, and generalization". Hal yang dikerjakan oleh saintis disebut sebagai proses sains, sedangkan hasilnya yang berupa fakta-fakta dan prinsip-prinsip disebut dengan produk sains.

Berkaitan dengan hakekat IPA di atas, maka pembelajarannyapun harus sesuai. Menurut Sudjana (2005), Pembelajaran IPA pada pelaksanaannya harus diupayakan dalam kondisi pembelajaran yang kondusif. Dalam artian bahwa pembelajaran harus bersifat aktif, kreatif, efektif, inovatif, dan menyenangkan. Artinya peran dan fungsi guru dalam pembelajaran harus dapat memberikan warna dan 
bentuk terhadap proses pembelajaran dan dapat menciptakan situasi kelas yang kondusif, sehingga tujuan pembelajaran dapat dicapai dengan optimal. Selain itu, guru juga diharapkan selalu menghubungkan materi dengan dunia nyata sehingga kegiatan pembelajaran menjadi lebih bermakna dan tidak mudah dilupakan oleh siswa. Dengan demikian, hasil belajar siswa menjadi lebih baik.

Namun kenyataan di lapangan, hasil belajar IPA siswa belum sesuai harapan. Hal serupa juga terjadi pada siswa kelas IVA SD Negeri 2 Sempidi. Berdasarkan pencatatan dokumen pada tanggal 28 September 2016, diperoleh informasi tentang pencapaian hasil belajar siswa SD Negeri 2 Sempidi. Hasil belajar siswa kelas IVA pada mata pelajaran IPA disajikan pada Tabel 1.1 berikut ini.

Tabel 1. Hasil Belajar Kelas IVA pada Mata Pelajaran IPA

\begin{tabular}{ll}
\hline Nilai siswa & Banyak siswa \\
\hline 80 & 1 orang \\
75 & 2 orang \\
70 & 1 orang \\
65 & 3 orang \\
60 & 11 orang \\
55 & 3 orang \\
\hline & (sumber : TU SD Negeri 2 Sempidi)
\end{tabular}

Tabel di atas menunjukkan bahwa rata-rata nilai hasil belajar IPA siswa kelas IV di SD Negeri 2 Sempidi adalah 62,8. Persentase rata-rata nilai tersebut adalah 62,8 \%. Persentase pada kategori tersebut berada pada kategori cukup.

Berdasarkan hasil observasi terhadap proses pembelajaran IPA pada siswa kelas IV SD Negeri 2 Sempidi Kabupaten Badung, ditemukan beberapa permasalahan sebagai penyebab rendahnya hasil belajar siswa. Permasalahan tersebut antara lain adalah pertama, pembelajaran yang dilaksanakan masih berpusat pada guru. Kedua, dalam proses pembelajaran guru tidak menghubungkan materi dengan masalah-masalah kehidupan nyata sehingga siswa hanya menyimak penjelasan dari guru dan terlalu pasif. Ketiga, guru kurang menggunakan media pembelajaran dalam pelaksanaan pembelajaran. Keempat, siswa lebih banyak diam dan enggan untuk bertanya apabila menemukan kesulitan atau belum mengerti dengan penjelasan guru. Kelima, siswa ragu dalam menjawab pertanyaan yang diajukan oleh guru/siswa lain.

Berdasarkan pemaparan masalah di atas, maka diupayakan suatu usaha untuk memperbaiki pembelajaran tersebut. Upaya yang dapat mengatasi masalah tersebut adalah penerapan proses pembelajaran yang mengupayakan siswa aktif dan mampu membangun pengetahuan yang akan menjadi miliknya. Berdasarkan upaya yang dilakukan ini metode yang tepat dan sejalan dengan karakteristik masalah yang diatasi adalah metode Take and Give.

Metode pembelajaran Take and Give (menerima dan memberi) merupakan metode pembelajaran yang memiliki langkah-langkah, yang menuntut siswa untuk mampu memahami materi pelajaran yang diberikan guru dan teman sebayanya (Suyatno, 2009). Menurut Hanafiah dan Suhana (2009), dalam pembelajaran kooperatif tipe Take and Give ini siswa diajak untuk berfikir dalam menyelesaikan tugas yang telah diberikan oleh guru.

Menurut Huda (2013) mengemukakan pendapatnya bahwa, Metode pembelajaran Take and Give adalah pembelajaran yang didukung oleh penyajian data yang diawali dengan pemberian kartu kepada siswa. Di dalam kartu, ada catatan yang harus dikuasai atau dihafal masing-masing siswa. Pembelajaran Take and Give merupakan "proses pembelajaran yang berusaha mengaitkan pengetahuan baru dengan pengetahuan yang telah dimiliki siswa" (Shoimin, 2014). Selanjutnya, Taufiq, (2011) menyatakan bahwa "Tugas utama guru bukan hanya mengajar tetapi membelajarkan anak, yaitu membuat anak aktif melakukan berbagai bentuk kegiatan, bukan hanya mendengarkan guru berbicara di depan kelas atau menuliskan sesuatu".

Menurut Shoimin (2014) kelebihan metode pembelajaran Take and Give adalah sebagai berikut: (1) Peserta didik akan lebih cepat memahami penguasaan materi dan informasi, karena mendapatkan informasi dari guru dan peserta didik yang lain, (2) Dapat menghemat waktu dalam pemahaman dan penguasaan peserta didik akan informasi, (3) Meningkatkan kemampuan untuk bekerja sama dan bersosialisasi, (4) Melatih kepekaan diri, empati melalui variasi perbedaan sikap dan tingkah laku selama bekerja, (5) Upaya mengurangi rasa kecemasan dan menumbuhkan rasa percaya diri, (6) Meningkatkan motivasi belajar, sikap dan tingkah laku yang positif serta meningkatkan prestasi belajarnya. Selanjutnya Huda (2013) mengemukakan kelebihan model pembelajaran Take and Give adalah sebagai berikut. (1) Dapat dimodifikasi sedemikian rupa sesuai dengan keinginan dan situasi pembelajaran, (2) Melatih peserta didik untuk bekerja sama dan saling menghargai kemampuan orang lain, (3) Melatih peserta didik 
untuk berinteraksi secara baik dengan teman sekelasnya, (4) Memperdalam dan mempertajam pengetahuan peserta didik melalui kartu yang dibagikan, (5) Meningkatkan tanggung jawab peserta didik, sebab masing-masing peserta didik dibebani pertanggungjawaban atas kartunya masing-masing, (6) Pesrta didik akan lebih cepat memahami penguasaan materi dan informasi karena mendapatkan informasi dari guru dan peserta didik yang lain

Keberhasilan penerapan metode Take and Give dalam penelitian ini, sejalan dengan penelitian yang dilakukan oleh Sugiantari (2016), " Penerapan Metode pembelajaran Take and Give berbantuan media Mind Mapping membantu meningkatkan keaktifan belajar dan hasil belajar IPA kelas IV SDN 2 Banjar Tegal Kecamatan Buleleng, Kabupaten Buleleng Semester II Tahun Pelajaran 2015/2016. Berdasarkan hasil penelitian, persentase rata-rata keaktifan belajar siswa pra siklus sebesar 31,82\%. Pada siklus I, persentase rata-rata keaktifan belajar siswa meningkat menjadi $67,41 \%$ dan pada siklus II meningkat menjadi 81,25 \%. Persentase rata-rata hasil belajar IPA siswa pra siklus sebesar 46,67\%. Pada siklus I, persentase rata-rata hasil belajar IPA meningkat menjadi $67,75 \%$ dan pada siklus II meningkat menjadi 80,75 \%. Hasil penelitian ii juga diperkuat oleh Osok (2014), dengan judul "Penerapan Metode Take and Give Untuk Meningkatkan Hasil Belajar IPA Tentang Mengenal Bagian-bagian Utama Tubuh Pada Siswa kelas II SD Negeri Teluk Dore Tahun Ajaran 2013/2014 “. Berdasarkan hasil penelitian yang telah dilakukannya, setelah menerapkan metode pembelajaran Take and Give, hasil belajar IPA pada siswa kelas II SD Negeri Teluk Dore mengalami peningkatan. Sebelum diberikan tindakan penelitian, rata-rata hasil belajar siswa hanya sebesar 45,68\%. Pada siklus I, rata-rata belajar IPA $71,43 \%$ dan pada siklus II meningkat menjadi 82,22 \%.

Atas dasar tersebut, maka perlu dilakukan suatu penelitian tindakan kelas. Penelitian yang dilakukan berjudul "Penerapan Metode Take and Give Untuk Meningkatkan Hasil Belajar IPA Siswa Kelas IVA SD Negeri 2 Sempidi Kecamatan Mengwi Tahun Pelajaran 2016/2017".

\section{Metode}

Jenis penelitian ini adalah Penelitian Tindakan Kelas yang dilaksanakan pada semester ganjil di SD No. 2 Sempidi, Kecamatan Mengwi Kabupaten Badung. Jenis penelitian tindakan yang digunakan adalah penelitian tindak kolaboratif, yaitu kolaborasi atau kerjasama antara guru dan peneliti. Peneliti dan guru ikut terlibat dalam setiap kegiatan siklus. Guru kelas bertindak sebagai observer dan peneliti bertindak sebagai pembelajar.

Penelitian ini dilaksanakan pada semester ganjil tahun pelajaran 2016/2017. Tempat penelitian adalah di kelas IVA SD Negeri 2 Sempidi Kecamatan Mengwi Kabupaten Badung pada mata pelajaran IPA. Subjek penelitian ini adalah seluruh siswa kelas IVA Semester ganjil SD No 2 Sempidi pada tahun pelajaran 2016/2017 sebanyak 21 orang. Mereka terdiri dari atas 11 orang siswa perempuan dan 10 orang siswa laki-laki.

Objek dari penelitian ini adalah hasil belajar siswa mata pelajaran IPA kelas IVA SD Negeri 2 Sempidi Kecamatan Mengwi Kabupaten Badung dan penerapan metode Take and Give.

Penelitian ini dilaksanakan dalam pola siklus. Artinya siklus selanjutnya ditentukan berdasarkan siklus sebelumnya, sampai diperoleh hasil yang diharapkan. Tindakan kelas (PTK) ini mengacu pada teori Stepen Kemmis dan Robin McTaggart. Agung (2005:91) mengemukakan bahwa "PTK terdiri atas empat tahapan, yaitu (1) perencanaan, (2) tindakan, (3) observasi/evaluasi, dan (4) refleksi, yang dilakukan secara berulang". Hal ini dapat digambarkan pada gambar berikut

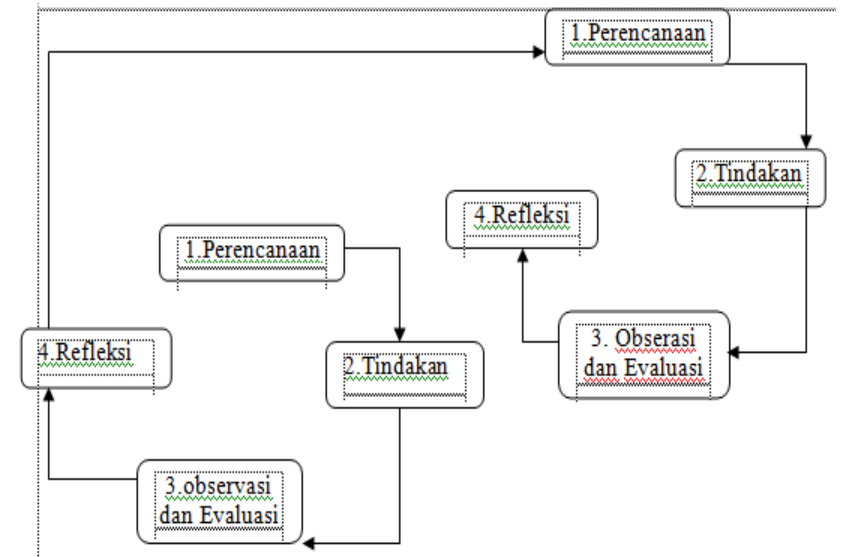

Gambar 1. Prosedur Penelitian Tindakan Kelas (Mulyasa, 2009) 
Pada tahap ini kegiatan yang dilaksanakan adalah mengamati segala fenomena yang terjadi selama proses tindakan, diantaranya aktivitas belajar dan kendala-kendala yang dialami dalam penerapan metode Take and Give. Aktivitas belajar IPA pada siswa diamati menggunakan lembar observasi. Observasi ini dilaksanakan pada saat pelaksanaan pembelajaran. Pada tiap akhir siklus dilaksanakan tes tertulis untuk melihat peningkatan kemampuan atau hasil belajar siswa sebelum dan setelah dilakukan tindakan terkait dengan materi yang telah diberikan.

Pelaksanaan tindakan yang dilakukan disesuaikan dengan rencana pembelajaran yang telah disusun. Kegiatan yang dilakukan dalam tahap ini adalah melaksanakan scenario pembelajaran dengan menggunakan metode Take and Give yang telah direncanakan. Setiap siklus terdiri dari 3 kali pertemuan, dengan 2 kali kegiatan pembelajaran dan 1 kali kegiatan tes akhir siklus.

Pada tahap observasi dan evaluasi kegiatan yang dilaksanakan adalah mengamati segala fenomena yang terjadi selama proses tindakan, diantaranya aktivitas belajar dan kendala-kendala yang dialami dalam penerapan metode Take and Give. Aktivitas belajar IPA pada siswa diamati menggunakan lembar observasi. Observasi ini dilaksanakan pada saat pelaksanaan pembelajaran. Pada tiap akhir siklus dilaksanakan tes tertulis untuk melihat peningkatan kemampuan atau hasil belajar siswa sebelum dan setelah dilakukan tindakan terkait dengan materi yang telah diberikan.

Kegiatan yang dilaksanakan pada tahap ini adalah menganalisis, memaknai, menjelaskan, dan menyimpulkan data yang diperoleh dari hasil observasi dan hasil tes yang telah diberikan kepada siswa. Tahap ini dilakukan untuk mengkaji hasil belajar siswa yang diperoleh setelah penerapan metode Take and Give. Hasil dari kegiatan ini berupa informasi yang digunakan sebagai dasar untuk merancang kegiatan yang dilaksanakan pada siklus selanjutnya.

Metode pengumpulan data disesuaikan dengan data yang diperoleh. Data yang dikumpulkan dalam penelitian ini adalah hasil belajar IPA siswa kelas IV dengan metode Take and Give. Metode yang digunakan dalam pengumpulan data pada penelitian ini adalah dengan tes. Metode tes dalam penelitian ini digunakan untuk mengumpulkan data mengenai hasil belajar siswa, yang dilaksanakan pada akhir pertemuan di masing-masing siklus.

Untuk memperoleh data dalam penelitian ini, diperlukan instrumen pengumpulan data yang menunjang kelancaran proses penelitian. Instrumen pengumpulan data yang digunakan adalah tes hasil belajar IPA. Tes yang digunakan adalah tes tertulis dalam bentuk obyektif yang berjumlah 20 .

Dalam penelitian ini, data dianalisis untuk menentukan mean dan persentase mean. Rumus yang digunakan sebagai berikut.

a) Untuk mencari mean atau skor rata-rata digunakan rumus sebagai berikut.

$$
M=\frac{\sum X}{N}
$$

(dalam Nurkancana dan Sunartana,1990)

Keterangan :

$$
\begin{array}{ll}
\mathrm{M} & =\text { Mean (rata-rata) } \\
\sum \mathrm{x} & =\text { Jumlah skor } \\
\mathrm{N} & =\text { Banyaknya siswa }
\end{array}
$$

b) Setelah diperoleh skor rata-rata hasil belajar siswa, data akan dihitung lagi ke dalam persentase $\mathrm{M}(\%)$ dengan rumus sebagai berikut.

$$
\begin{aligned}
& \mathrm{M} \%=\frac{\mathrm{M}}{\mathrm{SMI}} \times 100 \% \\
& \text { (dalam Agung, 1997) } \\
& \text { Keterangan: } \\
& \begin{array}{ll}
\mathrm{M} \%=\text { Skor rata-rata persen } \\
\mathrm{M} \quad \text { = Skor yang dicapai siswa }
\end{array} \\
& \text { SMI }=\text { Skocara keseluruhan (mean) }
\end{aligned}
$$

Dari hasil analisis persentase tingkat hasil belajar siswa yang diperoleh selanjutnya dikonversikan ke dalam Penilaian Acuan Patokan (PAP) skala lima dengan berpedoman pada kriteria seperti, pada tabel 1.2 berikut ini. 
Tabel 1.2 Kriteria Penggolongan Data Hasil Belajar

\begin{tabular}{ll}
\hline Persentase & Kriteria \\
\hline $90 \%-100 \%$ & Sangat tinggi \\
\hline $80 \%-88 \%$ & Tinggi \\
\hline $65 \%-79 \%$ & Sedang \\
\hline $55 \%-64 \%$ & Rendah \\
\hline $0 \%-54 \%$ & Sangat Rendah \\
\hline & Sumber: Nurkancana dan Sunartana $(1990)$
\end{tabular}

Indikator keberhasilan penelitian ini adalah persentase hasil belajar jika ditinjau dari hasil siswa mencapai $80 \%$ pada katagori tinggi. Apabila indikator keberhasilan pada pencapaian penguasaan materi sudah tercapai maka penelitian ini dihentikan.

\section{Hasil Dan Pembahasan}

Penelitian tindakan kelas ini dilaksanakan di kelas IVA SD No 2 Sempidi, Kabupaten Badung pada semester ganjil Tahun Pelajaran 2016/2017. Penelitian ini dilaksanakan mulai tanggal 10 Oktober 2016 sampai dengan 31 Oktober 2016. Metode tes digunakan untuk memperoleh data. Data yang diperoleh selanjutnya digunakan untuk menjawab masalah yang dirumuskan dalam penelitian. Analisis data siswa mengenai hasil belajar dalam pembelajaran IPA dapat dijelaskan sebagai berikut.

Siklus I dibagi menjadi tiga kali pertemuan. Pertemuan pertama adalah untuk membahas bagian akar pada tumbuhan beserta fungsinya. Pertemuan kedua membahas jenis-jenis batang pada tumbuhan beserta fungsinya. Pertemuan ketiga adalah untuk melaksanakan kegiatan evaluasi akhir siklus. Dalam seminggu dilaksanakan tiga kali pertemuan, dengan alokasi waktu tiap pertemuan 70 menit $(2 \times 35$ menit). Berdasarkan hasil analisis data hasil belajar IPA siswa, didapatkan persentase rata-rata siklus I adalah $70,9 \%$ dan dikonversikan terhadap penilaian acuan patokan (PAP) skala 5 berada pada kategori Sedang.

Pada siklus II dibagi menjadi tiga kali pertemuan. Pertemuan pertama untuk membahas bagianbagian daun, bentuk tulang daun, macam susunan daun pada tumbuhan beserta fungsinya. Pertemuan kedua membahas bagian-bagian bunga dan jenis-jenis bunga pada tumbuhan berserta fungsinya. Pertemuan ketiga adalah untuk melaksanakan kegiatan evaluasi akhir siklus. Dalam seminggu dilaksanakan tiga kali pertemuan dengan alokasi waktu 70 menit ( 2 x 35 menit). Berdasarkan hasil analisis data hasil belajar IPA siswa, didapatkan persentase rata-rata siklus II adalah 81,4\% dan dikonversikan ke dalam tabel penilaian acuan patokan (PAP) skala 5 berada pada katagori Tinggi.

Persentase rata-rata hasil belajar IPA siswa adalah 81,4\%,bila dikonversikan pada tabel penilaian acuan patokan (PAP), persentase tersebut berada interval 80\% - 89\% dengan kriteria tinggi. Berdasarkan hasil analisis data di atas, dapat diketahui bahwa penerapan metode Take and Give menunjukkan adanya keberhasilan dalam upaya meningkatkan hasil belajar siswa. Oleh karena itu, penelitian ini dihentikan karena telah tercapai indikator keberhasilan yang ditetapkan.

Berdasarkan hasil analisis data dan refleksi di atas, maka penelitian dihentikan hingga siklus II. Selanjutnya persentase rata-rata hasil belajar masing-masing siklus ditampilkan pada grafik 1.1 berikut ini.

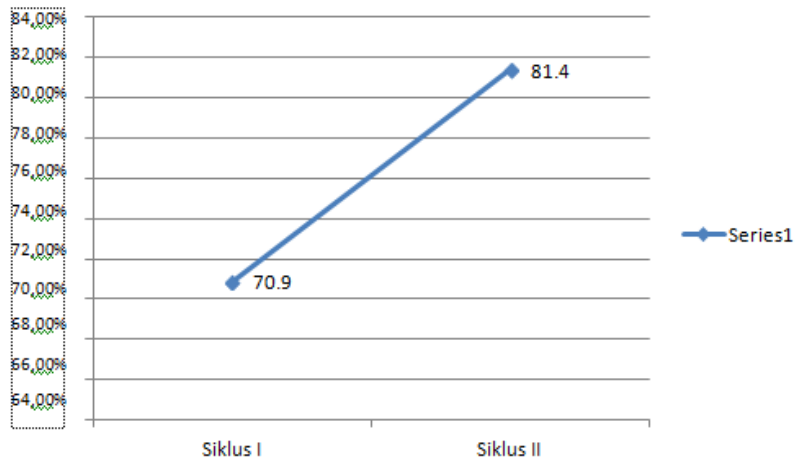

Gambar 2. Rata-Rata Hasil Belajar Masing-Masing Siklus

Pada siklus I, rata-rata persentase hasil belajar IPA siswa sebesar 70,9\% berada pada kategori sedang dan pada siklus II meningkat menjadi 81,4\% berada pada kategori tinggi. Berdasarkan hasil tersebut, terjadi peningkatan persentase dari siklus I hingga siklus II sebesar 10,5\%. 
Peningkatan persentase pada rata-rata dari pra siklus hingga siklus II dapat terjadi karena pertama, pembelajaran yang menerapkan metode Take and Give dapat mengubah pembelajaran yang awalnya hanya berpusat kepada guru menjadi pembelajaran berpusat siswa. Penerapan metode pembelajaran Take and Give mampu meningkatkan hasil belajar siswa kelas IVA di SD Nomor 2 Sempidi, Metode Take and Give dapat menjadikan pembelajaran berpusat pada siswa. Siswa akan lebih aktif dan mampu membangun pengetahuan yang akan menjadi miliknya. Selain itu, siswa akan lebih cepat memahami penguasaan materi dan informasi karena mendapatkan informasi dari guru dan temannya. Hal ini membuat siswa belajar bermakna sehingga berdampak terhadap perolehan hasil belajar siswa. Pendapat ini sejalan dengan pendapat Dahar (1988:137) yang menyatakan bahwa "belajar dikatakan bermakna jika informasi yang dipelajari siswa disusun sesuai dengan struktur kognitif yang dimilikinya, sehingga siswa dapat mengaitkan informasi barunya dengan struktur kognitif yang dimlikinya maka hasil belajar siswa pun dapat meningkat" Selanjutnya, pemberian reward berupa tambahan nilai untuk siswa yang menjawab pertanyaan dengan benar membuat siswa tidak ragu-ragu saat menjawab pertanyaan yang diberikan oleh guru. Pemberian nilai saat menjawab benar lebih bersemangat dan meningkatkan partisipasi siswa dalam proses pembelajaran. Partisipasi dalam kegiatan pembelajaran dapat menyebabkan motivasi siswa dalam belajar meningkat. Peningkatan motivasi dapat membuat siswa mencapai tujuannya, sehingga hasil belajar siswa tersebut menjadi optimal. Jaelani (2011) menyatakan bahwa adanya motivasi yang baik dalam belajar akan menunjukkan hasil yang baik pula.

Keberhasilan penerapan metode Take and Give dalam penelitian ini, sejalan dengan penelitian yang dilakukan oleh Sugiantari (2016), “ Penerapan Metode pembelajaran Take and Give berbantuan media Mind Mapping membantu meningkatkan keaktifan belajar dan hasil belajar IPA kelas IV SDN 2 Banjar Tegal Kecamatan Buleleng, Kabupaten Buleleng Semester II Tahun Pelajaran 2015/2016. Berdasarkan hasil penelitian, persentase rata-rata keaktifan belajar siswa pra siklus sebesar 31,82\%. Pada siklus I, persentase rata-rata keaktifan belajar siswa meningkat menjadi $67,41 \%$ dan pada siklus II meningkat menjadi 81,25 \%. Persentase rata-rata hasil belajar IPA siswa pra siklus sebesar 46,67\%. Pada siklus I, persentase rata-rata hasil belajar IPA meningkat menjadi 67,75\% dan pada siklus II meningkat menjadi $80,75 \%$.

Hasil penelitian ini juga diperkuat oleh Osok (2014), dengan judul "Penerapan Metode Take and Give Untuk Meningkatkan Hasil Belajar IPA Tentang Mengenal Bagian-bagian Utama Tubuh Pada Siswa kelas II SD Negeri Teluk Dore Tahun Ajaran 2013/2014 “. Berdasarkan hasil penelitian yang telah dilakukannya, setelah menerapkan metode pembelajaran Take and Give, hasil belajar IPA pada siswa kelas II SD Negeri Teluk Dore mengalami peningkatan. Sebelum diberikan tindakan penelitian, rata-rata hasil belajar siswa hanya sebesar $45,68 \%$. Pada siklus I, rata-rata belajar IPA 71,43\% dan pada siklus II meningkat menjadi $82,22 \%$.

Sesuai dengan penelitian yang telah dilakukan oleh Sugiantari dan Osok yang menyatakan keberhasilannya dalam menerapkan metode Take and Give, peneliti juga mendapatkan hasil yang baik dengan menerapkan metode pembelajaran yang sama. Berdasarkan paparan diatas, dengan metode pembelajaran Take and Give memberikan hasil yang positif dalam meningkatkan hasil belajar siswa baik dari ranah kognitif khususnya. Ini berarti hipotesis yang diajukan peneliti yaitu Penerapan metode Take and Give untuk meningkatkan hasil belajar IPA kelas IV A SD Negeri 2 sempidi kecamatan mengwi tahun pelajaran 2016/2017 “dapat diterima.

\section{Simpulan Dan Saran}

Berdasarkan pembahasan hasil penelitian, maka dapat disimpulkan sebagai berikut. Penerapan metode Take and Give dapat meningkatkan hasil belajar IPA siswa kelas IVA Semester ganjil SD Nomor 2 Sempidi Tahun Pembelajaran 2016/2017. Hal ini dapat dilihat dari peningkatan persentase rata-rata hasil belajar yang diperoleh. Pada siklus I diperoleh rata-rata hasil belajar sebesar 70,9\% yang berada pada kriteria "sedang". Pada siklus II diperoleh rata-rata hasil belajar sebesar $81,4 \%$ berada pada kriteria "Tinggi".

Berdasarkan simpulan di atas, disampaikan beberapa saran sebagai berikut. pertama Kepada Guru Agar Guru hendaknya dapat melanjutkan penerapan metode Take and Give sebagai salah satu strategi untuk meningkatkan partisipasi siswa dalam proses pembelajaran, sehingga dapat meningkatkan hasil belajar siswa secara berkelanjutan. Kedua Kepada Kepala Sekolah Agar Kepala sekolah hendaknya dapat menciptakan kondisi yang mampu mendorong para guru untuk mencoba menerapkan metode Take and Give dalam pembelajaran sebagai upaya meningkatkan hasil belajar siswa. dan ketiga Kepada Peneliti Lain Agar Peneliti lain hendaknya hasil penelitian ini dengan memperhatikan kendala-kendala yang dialami sebagai bahan pertimbangan untuk perbaikan dan menyempurnakan pelaksanaan penelitian berikutnya 


\section{Daftar Pustaka}

Angga Wiguna, Sang Gede., I Wayan Widiana, Dewa Nyoman Sudana. Penerapan Pembelajaran Berbasis Otak Untuk Meningkatkan Kemampuan Pemecahan Masalah Matematika Siswa Kelas V Sekolah Dasar. Mimbar PGSD Vol 5 No 2 Tahun 2016. (http://ejournal.undiksha.ac.id/index.php/JJPGSD/ article/view/7776).

Agung, A.A Gede. 2010. Metedologi Penelitian Pendidikan. Singaraja: Aditya Media Publishing.

Agusditya, Putu Handy., I.G.A.A. Sri Asri, I Made Suara. The Effect of Scientific Approach Based on Portfolio Assessment towards the Learning Outcomes of Civic Education of the Students Grade V Viewed from the Tendency of Observing Objects on Theme 7 SDN 4 Ubung. Journal of Evaluation and Research in Education (JERE) Vol 1 No 1 Tahun 2017. (http://ejournal.undiksha.ac.id/ index.php/JERE/article/view/9842).

Agus Suarimbawa, Kadek., A. A. I. N. Marhaeni, GAP Suprianti. 2017. An Analysis of Authentic Assessment Implementation Based on Curriculum 2013 in SMP Negeri 4 Singaraja. Journal of Evaluation and Research in Education (JERE) Vol 1 No 1 Tahun 2017 (http://ejournal.undiksha.ac.id/ index.php/JERE/article/view/9551).

Bundu, Patta. (2006). Penilaian Keterampilan Proses dan Sikap Ilmiah dalam Pembelajaran Sains di SD. Jakarta : Depdiknas.

Dahar, Ratna Wilis. 1988. Teori-teori Belajar. Bandung: Erlangga.

Darmodjo dan Kaligis. 1992. Pendidikan IPA 2. Jakarta: Departemen Pendidikan dan Kebudayaan.

Darmojo, Hendro., Jenny R.E Kaligis. 1993. Pendidikan IPA 2. Jakarta: Depdikbud.

Dimyanti dan Moedjiono .1999.Strategi Belajar Mengajar. Jakarta. Depdikdud.

Hadi, L. S., Agustriyana, Subagiyo Subagiyo. 2017. Project Based Learning on Casting of Aluminium Tensile Test Specimen for Mechanical Engineering Students, State Polytechnic of Malang on Odd Semester of Academic Year 2016/2017. Journal of Evaluation and Research in Education (JERE) Vol 1 No 1 Tahun 2017. (http://ejournal.undiksha.ac.id/ index.php/JERE/article/view/9844).

Hamalik. 2001 . Proses Belajar Mengajar. Jakarta: Bumi Aksara.

Hanafiah, N. dan Suhana, C. 2009. Konsep Strategi Pembelajaran. Refika Aditama. Bandung.

Huda, Miftahul. 2013. Model-model Pengajaran dan Pembelajaran Isu-isu Metodis dan Paradigmatis. Yogyakarta : Pustaka Belajar.

Januarti, Ni Ketut., I Ketut Dibia, I Wayan Widiana. 2016. Analisis Kesulitan Belajar Dalam Pembelajaran Membaca Cepat Siswa Kelas V Sd Gugus Vi Kecamatan Abang. Mimbar PGSD Vol 4 No 1 Tahun 2016. (http://ejournal.undiksha.ac.id/index.php/JJPGSD/ article/view/7442).

Jasdilla. 2016. Hasil Belajar Dan Pembelajaran Kooperatif Tipe Think Pair Share (Tps). Journal Pendidikan Indonesia P-ISSN: 2303-288X E-ISSN: 2541-7207 Vol. 6, No.1, April 2016. http://ejournal.undiksha.ac.id/index.php/JPI/article/view/9253/6328

Laba Laksana, Dek Ngurah. 2016. Miskonsepsi Dalam Materi IPA Sekolah Dasar. Jurnal Pendidikan

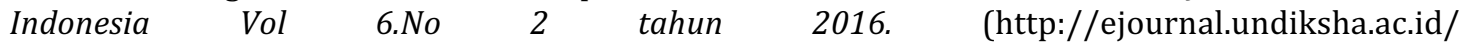
index.php/JPI/article/view/8588).

Jaelani.2011. Teori Motivasi Belajar .Jakarta: Rajawali Press

Kurniasih Imas \& Sani Berlin. 2015.Model Pembelajaran. Jogjakarta: Katapena.

Lie, Anita. 2007. Cooperative Learning. Jakarta : Grasindo

Oka Sugiarta, Gst Pt., I Wayan Widiana, I Dewa Kade Tastra. Penerapan Model Pembelajaran Akselerasi (Accelerated Learning) Untuk Meningkatkan Hasil Belajar Ipa Siswa Kelas V di SD N 8 Banyuning. Mimbar PGSD Vol 6 No 3 Tahun 2016. (http://ejournal.undiksha.ac.id/index.php/JJPGSD/ article/view/8600).

Mulyasa. 2009. Praktik Penelitian Kelas. Bandung : PT Remaja Rosdakarya

Nurkancana, Wayan, dan PPN Sunartana. 1990. Evaluasi Hasil Belajar. Surabaya: Usaha Nasional 
Rustaman, Nuryani. 2011. Materi dan Pembelajaran IPA SD. Jakarta: Universitas Terbuka.

Shoimin, Aris. 2014. 68 Model Pembelajaran Inovatif dalam Kurikulum 2013, Yogyakarta : Ar- Ruzz Media.

Septiani Ari Pertiwi, Ni Luh., Ni Wayan Arini, I Wayan Widiana. 2016. analisis Tes Formatif Bahasa Indonesia Kelas IV Ditinjau Dari Taksonomi Bloom Revisi di Gugus XIII Kecamatan Buleleng Tahun Ajaran 2015/2016. Mimbar PGSD Vol 5 No 2 Tahun 2016. (http://ejournal.undiksha.ac.id/index.php/JJPGSD/article/view/7692).

Shoimin. 2014. 68. Model Pembelajaran Inovatif dalam Kurikulum 2013, Yogyakarta : Ar-RuzzMedia.

Susanto, Ahmad, 2013. Teori Belajar Pembelajaran. Fajar Interpratama Mandiri. Jakarta: Kencana

Suyatno, Huda. 2009. Pembelajaran Inovatif. Sidoarjo: Masmedia Buana Pustaka.

Suyatno. 2009. Menjelajah Pembelajaran Inovatif. Jawa Timur : Masmedia Buana Pustaka

Tanindra, Tukiran dkk. 2015. .Model-Model Pembelajaran Inovatif dan Efektif. Bandung: Alfabeta.

Taufiq, Agus. 2010. Pendidikan Anak di SD. Jakarta: Universitas Terbuka.

Trianto. 2011. Penelitian Tindakan Kelas. Jakarta: Prestasi Pusat Karya

Widiana, dkk. 2014. Pengaruh Model Pembelajaran Kooperatif Tipe Think Pair Square (Tps) Berbantuan Kartu Kerja Terhadap Hasil Belajar Matematika. Jurnal Mimbar PGSD Universitas Pendidikan Ganesha Jurusan PGSD (Vol: 2 No: 1 Tahun 2014).

Widiana, I Wayan. 2016. Pengembangan Asesmen Proyek Dalam Pembelajaran IPA di Sekolah Dasar. Jurnal Pendidikan Indonesia Vol 6.No 2 tahun 2016. (http://ejournal.undiksha.ac.id/ index.php/JPI/article/view/8154). 